\title{
The Role of Personality Qualities in Driving
}

\author{
M. Šucha* \& M. Seitl \\ Department of Psychology, Philosophical Faculty, Palacky University in Olomouc \\ * Corresponding author: matus.sucha@upol.cz
}

DOI: $10.2478 / \mathrm{v} 10158-011-0019-3$

\begin{abstract}
The main cause of traffic accidents is the human element. This implies that the most significant traffic safety factor is the driver's behaviour and their psychological qualifications for driving (Antušek, 1998; Havlík, 2005; Stránský, 2000; Štikar, Hoskovec \& Štikarová, 2003). Generally, the driver's behaviour reflects their personality characteristics and the specific situation. The present article focuses on the personality variables which, according to recent research, are particularly associated with the driving of motor vehicles. The personality characteristics, of which the understanding is important for the development of a methodology for the selection of suitable candidates for the position of a driver, are described. The role of personality in a narrow sense, the specific qualities of a driver and a risky driver, the individual traits posing risk in terms of driving, and aggressiveness are also addressed.
\end{abstract}

KEY WORDS: driver, personality, safety.

\section{PERSONALITY}

Personality psychology still features a plurality of conceptual frameworks, as scholars have failed to reach consensus about the definition of personality. The literature provides a range of notions of the personality and approaches to its study. Cloninger (2009), for example, refers to the following main perspectives of personality studies: biological, cognitive, humanistic, dynamic, the learning theory and the trait approach. For each of the approaches, their key concepts and representatives are also stated.

One of the prominent authors who tried to define personality by means of compiling others' definitions was G. W. Allport. In 1937 Allport posited that "personality is the dynamic organization within the individual of those psychophysical systems that determine his unique adjustments to the environment." (Allport, 1937, p. 48). The personality characteristics may be used to infer how individuals behave within their environment and experience it, including road traffic. Nevertheless, predictions will never be perfect - "people are strongly influenced 
by situations and, moreover, most behaviours are the expression of several traits - no perfect consistency in behaviour may be expected" (Allport, 1937, in Pervin, 2003, p. 40).

The basic categories of personality psychology are the structure and the dynamics. Nakonečný (2009) defines the structure of personality as the inner arrangement (a configuration of components, dispositions, or elements) of personality which indicates a more permanent state of the psychological determination of a human being. In addition, he suggests the existence of two categories of psychological characteristics of personality: a) characteristics of the properties of psychological processes (such as memory, thinking, and perception), b) characteristics of the psychological qualities of personality. It is the latter that this chapter will focus on.

According to Mikšík (2007), personality qualities may be divided into substructures: a) character qualities (including temperament and types and forms of behaviour), b) the motivational system (focus, content, direction of interactions), and c) abilities.

The personality dynamics gives the individual personality structures an "impetus", determines the focus on the achievement of a goal, and motivates behaviour. Personality blends in itself an array of motivational tendencies to behaviour which, together with certain dispositions in the structure of the personality, constitute a variability and make each human personality unique (Nakonečný, 2009).

\subsection{Personality Traits}

The trait approach to personality psychology was made famous by R. Cattell. His theory is based on a descriptive approach to personality (traits constitute the principal elements). He places an emphasis on prediction and applies the psychometric approach (Drapela, 2003). This perspective is suitable in describing personality in a situation of high demands on a standardised process, speed, and the effectiveness of psychodiagnostic assessment, which is exactly what is needed in traffic-psychology diagnosis.

Helus (2003) views personality traits as partial qualities of personality that provide longterm characteristics and are bound to specific situations (e.g., a human resources professional needs to know whether a candidate for the position of an air traffic controller can follow several panels at the same time and their attention does not waver for a set period of time).

English and English (in Kolaříková, 2005) suggest that a trait is an enduring characteristic of a person which makes it possible to distinguish such a person from others and is consistently manifested despite numerous changes in the external circumstances.

\subsection{Driver's Personality}

Within the system of transportation (driver - means of transport - traffic environment), the driver stands as a high-risk element. One of the reasons is the very personality of the driver, which is unique and irreproducible.

Each personality's uniqueness also makes it difficult to find a standard method of assessing the driver's personality that can capture the individual features of each personality qualified for driving. Only the qualities that are generally beneficial and risky for the personality of a driver can be identified. Two such categorisations from the perspective of traffic psychology are presented below.

Antušek (1998) suggests that the driver's conduct is especially influenced by their temperament and character. Good drivers tend to have well-balanced and strong types of nervous system; their reactions are accurate and quick. On the other hand, problem drivers 
show elements of irresponsibility, lack of caution, impulsiveness, emotional hypersensitivity, and sometimes indecisiveness and anxiousness.

"The personality of a problem-free driver features a well-balanced structure, emotional stability, adaptability, self-control, reasonable self-confidence, resilience to stress, conscientiousness, and reliability. Social qualities, such as altruism expressed by the effort to think of others and predict their behaviour, should not be disregarded either" (Havlík, 2005, p. 13).

On the contrary, drivers who cause traffic accidents more often tend to be more peculiar, egocentric, dynamic, aggressive, and emotional, and have reduced self-regulation, a disharmoniously structured personality, and impaired self-esteem, but show reasonable psychological performance. Unfailing individuals are efficient, adaptable, responsible, and emotionally stable, and can control themselves and cope with difficulties and stress (Havlík, 2005).

\subsection{Driver Typologies}

Research studies have arranged risky drivers into various typologies in order to identify different categories and qualities which are hazardous for traffic situations. Such efforts were intended to facilitate better orientation in assessing people's qualifications for driving.

One of the oldest typologies is that of Chorvát and Orlík (1980). It introduces six types of dangerous drivers whom we should avoid in road traffic or in the presence of whom we should at least be very alert (racer, gambler, exhibitionist, chaser, rusher, and faintheart).

Larson (1996, in Šmolíková, Hoskovec, \& Štikar, 2008) developed a typology comprising five types of aggressive drivers:

1. the Speeder - tries to reach the destination as soon as possible. When others get in their way, they quickly become enraged;

2. the Competitor - tries to beat other drivers, competing with them on the road;

3. the Passive Aggressor - obstructs others' attempts at overtaking, driving fast, and merging; challenges other drivers' self-confidence;

4. the Narcissist - shows rigid driving behaviour and becomes angry when others do not drive in the same manner, and

5. the Vigilante - feels himself to be a superior judge of other drivers and seeks to punish them for any of their violations.

Using the data collected from 2524 respondents, Ulleberg (2001) distinguished six subtypes of driver personality and identified the two subtypes posing the highest risk. He suggests that the riskiest drivers are males characterised by low levels of altruism and anxiety and high levels of sensation seeking, irresponsibility, and driving-related aggression. The second high-risk group consists of people showing high levels of sensation seeking, aggression, and anxiety, and inclined to driving anger. Moreover, the two highestrisk types are the least responsive to traffic safety campaigns.

Two more typologies, presented by Štikar, Hoskovec, and Štikarová (2003), are provided below for illustration. 
The one proposed by McGuire accounts for six groups of drivers. The first group comprised well-balanced and efficient individuals who are excellent drivers in terms of accident involvement. Groups 2-5 suffer from emotional problems, while Group 6 encompasses people who are physically or mentally ill. The characteristics of each group are summarised in Table 1.

Table 1: Personality groups identified among drivers and behaviours typical of the drivers belonging to each group (in Štikar, Hoskovec, \& Štikarová, 2003, p. 148).

\begin{tabular}{|c|c|}
\hline Groups & Driving behaviour \\
\hline $\begin{array}{l}\text { 1) Well adapted; they seldom become } \\
\text { disconcerted and collect themselves } \\
\text { quickly. }\end{array}$ & $\begin{array}{l}\text { Do not tend to be involved in accidents } \\
\text { or violate traffic regulations. }\end{array}$ \\
\hline $\begin{array}{l}\text { 2) Have mental problems, but are socially } \\
\text { responsible and control themselves. }\end{array}$ & $\begin{array}{l}\text { Do not tend to be involved in accidents } \\
\text { or violate traffic regulations. }\end{array}$ \\
\hline $\begin{array}{l}\text { 3) Have mental problems, but are socially } \\
\text { responsible, but may become } \\
\text { disconcerted over long periods of time. }\end{array}$ & $\begin{array}{l}\text { May be prone to accidents and traffic } \\
\text { violations within certain periods of time } \\
\text { (weeks or months). }\end{array}$ \\
\hline $\begin{array}{l}\text { 4) Socially responsible, but have mental } \\
\text { problems and inclinations to being } \\
\text { permanently distempered. }\end{array}$ & $\begin{array}{l}\text { Involved in a large number of accidents } \\
\text { and violate regulations frequently. }\end{array}$ \\
\hline $\begin{array}{l}\text { 5) Show permanent tendency } \\
\text { to unsociable or antisocial behaviour. }\end{array}$ & $\begin{array}{l}\text { Chronic violators of traffic regulations } \\
\text { who may show high accident rates. }\end{array}$ \\
\hline $\begin{array}{l}\text { 6) Miscellaneous (epileptics, diabetics, } \\
\text { the mentally defective, etc.) }\end{array}$ & $\begin{array}{l}\text { Unpredictable behaviour; driving } \\
\text { behaviour may range from very bad } \\
\text { to very good. }\end{array}$ \\
\hline
\end{tabular}

On the other hand, Quenault's typology divides drivers into four groups, also taking into account, in addition to the observation of their driving behaviour in terms of speed and overtaking, their unusual manoeuvring and use of rear-view mirrors (Štikar, Hoskovec, \& Štikarová, 2003).

\section{CHARACTERISTICS OF A RISKY DRIVER}

The personality characteristics of a bad - risky - driver need to be stated in order to identify the key qualities necessary for the determination of the methods of selection of suitable candidates qualified for driving a vehicle.

\footnotetext{
* The originally used terminology has currently been replaced by terms which emphasise the disorders and illness rather than their bearers.
} 
As early as 1940 Selling recognised the relationship between personality and risky driving among his psychiatric patients with a history of frequent road accidents (Selling, 1940).

The relationship between personality traits and risky driving may be conceptualised by means of drivers' attitudes (Ulleberg \& Rundmo, 2003). The risky drivers' attitudes mostly concern factors such as obedience to traffic rules, a tendency to take chances in traffic jams, and positive attitudes to traffic jams (Yilmaz \& Çelik, 2004). West and Hall (1997) adopt a similar view by regarding positive attitudes to road violence as significant predictors of traffic accidents.

Perpetrators of road accidents tend to be unstable, extrovert, less adapted individuals with lower intelligence and inclinations to aggressive conduct (Fernandez-Seara, 1978). Štikar, Hoskovec, and Štikarová (2003) provide evidence that drivers with a higher record of accidents are likely to be eccentric, impulsive, and psychopathic.

People who are prone to risky behaviour (particularly those who are immature) often show little responsibility towards others and an insufficiently developed ability to anticipate, seek situational excitement and adventures, like to flaunt themselves in front of others, and show false self-confidence and the need to compensate for their sense of inferiority (Stojan et al., 2008). Research conducted by Machin and Sankey (2008) showed that inexperienced drivers underestimate the risks connected to a number of driving situations.

Aspects of personality traits considered by Stránský (2000) as contraindications for driving include emotional instability, maladaptivity, egocentrism with excessively increased self-esteem, hypersensitivity, irritability, intolerance, impatience, and chronic dissatisfaction. Other such traits include timidity or, on the contrary, carelessness, recklessness, irresponsibility, the inability to consider the consequences of one's actions, a lack of self-discipline, clear-cut antisocial attitudes, a strong need to assert oneself, aggressiveness, and negative attitudes towards the safety of oneself and others.

According to Hanzlíková (2004), the predominant traits of high-risk or dangerous drivers include little responsibility for their own actions, hostile attitudes to people, emotional instability, the unpredictability of their reactions, low tolerance of frustration and resistance to stress, poor self-control, tendencies to irritability, and aggressiveness. In addition, Hanzlíková reports on earlier findings made by Mikšík, who attempted to draw up a personality profile of "accident-prone" drivers using the IHAVEZ and SPIDO questionnaires. Mikšík found that their significant traits include lower personality self-regulation and inner control related to a reduced degree of anticipation and responsibility, carelessness and a tendency to take chances, emotional excitability and instability, unregulated emotionality, reduced variability of emotional adaptability, situation-induced disorientation, a loss of self-confidence, and the failure of an integrated way of dealing with a "surprising" development of a situation.

\subsection{Selected elements of driver's personality}

On the basis of the above-mentioned typologies and research into risky characteristics of drivers reported in both the Czech and foreign literature, we provide the following summary of a driver's risky personality variables:

a) Personality trait characteristics:

- dominance, the need to assert oneself, egocentrism,

- emotional stability $\times$ instability (neuroticism), 
- hypersensitivity, anxiety,

- level of self-confidence, self-esteem,

- extraversion $\times$ introversion,

- self-control, self-discipline, obedience to traffic regulations,

- conscientiousness,

- low tolerance of frustration and stress resistance, psychological resilience and fatigue.

b) Other aspects of personality with an impact on driving:

- type A behaviour,

- seeking of situational excitement and adventure; sensation-seeking,

- antisocial attitudes $\times$ prosocial attitudes, altruism,

- LOC - internal locus of control with reduced anticipation,

- attribution.

c) Aggressive tendencies:

- aggressiveness,

- aggression,

- anger,

- hostility.

\section{CONCLUSION}

Special attention should be paid to the above characteristics in the psychological testing and selection of drivers in order to prevent the failure of the human factor in road traffic. As suggested in the present article, the driver's personality features a range of factors which are potentially indicative of the driver's risky behaviour. These potential factors are triggered in combination with specific situational variables. Therefore, it is recommended that the testing and selection of drivers should especially consider the context of the driver's performance and focus on the personality characteristics that play the key role in the given situational context.

\section{REFERENCES}

Allport, G. W. (1937). Personality: A psychological interpretation. New York: Holt.

Antušek, I. (1998). Lexikon začínajícího řidiče. Praha: Grada Publishing. 
Chorvát, F., \& Orlík, J. (1980). Za volantom človek. Bratislava: Šport Blava.

Cloninger, S. (2009). Conceptual issues in personality theory. In P. Corr \& G.

Matthews (Eds.), The Cambridge Handbook of Personality Psychology, 3-26. Cambridge: Cambridge University Press.

Drapela, V. (2003). Přehled teorií osobnosti. Praha: Portál.

Fernandez-Seara, J. L. (1978). Psychology of the automobile driver: Personality factors of drivers with multiple accidents. Revista de Psicología General y Aplicada, 33, 217-228.

Hanzlíková, I. (2004). Proč selháváme za volantem. Psychologie dnes, 6, 14-15.

Havlík, K. (2005). Psychologie pro řidiče. Zásady chování za volantem a prevence dopravni nehodovosti. Praha: Portál.

Helus, Z. (2003). Osobnost a její vývoj. Praha: Univerzita Karlova v Praze.

Kolaříková, O. (2005) Téma osobnostnich rysů v psychologii dvacátého století. Praha: Academia.

Machin, M. A., \& Sankey, K. S. (2008). Relationships between young drivers' personality characteristics, risk perceptions, and driving behaviour. Accident Analysis and Prevention, 40 (2), 541-547.

Mikšík, O. (2007). Psychologická charakteristika osobnosti. Praha: Karolinum.

Nakonečný, M. (2009). Psychologie osobnosti. Praha: Academia.

Pervin, L. A. (2003). The Science of Personality. New York: Oxford University Press.

Selling, L. S. (1940). Personality traits observed in automobile drivers. Journal of Criminal Psychopathology, 1, 258-263.

Štikar, J., Hoskovec, J., \& Štikarová, J. (2003). Psychologie v dopravě. Praha: Karolinum.

Stojan, M. et al. (2008). Dopravní výchova dětí a mládeže jako jeden z pilíruo ochrany zdraví a prevence úrazů. Brno: Pedagogická fakulta Masarykovy Univerzity.

Stránský, Z. (2000). Psychologie v praxi bezpečnosti silničního provozu. In Sborník prací filozofické fakulty brněnské univerzity P4, 175-184. Brno: Masarykova univerzita. 
Stránský, Z. (2000). Psychologie v praxi bezpečnosti silničního provozu. In Sborník prací filozofické fakulty brněnské univerzity P4, 175-184. Brno: Masarykova univerzita.

Ulleberg, P. (2001). Personality subtypes of young drivers. Relationship to risk-taking preferences, accident involvement, and response to a traffic safety campaign. Transportation research Part F: Traffic Psychology and Behaviour, 4 (4), 279-297.

Ulleberg, P., \& Rundmo, T. (2003). Personality, attitudes and risk perception as predictors of risky driving behaviour among young drivers. Safety Science, 41 (5), 427-443.

West, R., \& Hall, J. (1997). The role of personality and attitudes in traffic accident risk. Applied Psychology: An International Review, 46 (3), 253-264.

Yilmaz, V., \& Çelik, H. E. (2004). A model for risky driving attitudes in Turkey.

Social Behavior \& Personality: An International Journal, 32 (8), 791-795.

The article was produced under the support of the project

Transport R \& D Centre ( CZ.1.05/2.1.00/03.0064 ). 